\title{
Genome size estimation of three stingless bee species (Hymenoptera, Meliponinae) by flow cytometry*
}

\author{
Denilce Meneses LOPES, Carlos Roberto de CARVALHO, \\ Wellington Ronildo ClaRINDO, Milene Miranda PRAÇA, Mara Garcia TAVARES
}

Departamento de Biologia Geral, Universidade Federal de Viçosa, Av. P H Rolfs, s/n , CEP: 36.570-000, Viçosa, Minas Gerais, Brazil

Received 2 July 2008 - Revised 26 November 2008 - Accepted 2 December 2008

\begin{abstract}
The present study standardizes a reproducible flow cytometry (FCM) protocol for DNA content measurement of bee species and applied it to Scaptotrigona and Melipona species. The mean nuclear DNA content value of male and female S. xantotricha was $0.42 \mathrm{pg}$ (410.8 Mbp) and $0.44 \mathrm{pg}$ (430.3 Mbp), respectively, while the mean haploid genome size was determined to be $0.93 \mathrm{pg}$ (909.5 Mbp) for M. rufiventris and $0.95 \mathrm{pg}$ (929.1 Mbp) for M. mondury. The variation observed in this study, albeit in a preliminary way, may be related with the variation in the heterochromatin content in the chromosomes of Scaptotrigona and Melipona species. The results provide a starting point for comparative analysis on the patterns of genome size variation in the stingless bees.
\end{abstract}

flow cytometry / genome size / Hymenoptera / stingless bees

\section{INTRODUCTION}

The haploid genome sizes of insects ranges from 0.09 picogram (pg) (Mayetiola destructor) to $16.93 \mathrm{pg}$ (Podisma pedestris), with an average of $1.29 \mathrm{pg} \pm 0.10$ (Gregory, 2008). Most of the 602 insect $C$-values measured to date, however, belong to the orders Diptera, Coleoptera, Orthoptera and Hemiptera (Gregory, 2008). Specifically in Hymenoptera, one of the largest insect orders, with approximately 115.000 species described (La Salle and Gauld, 1993), the genome size has been measured in fifty two species: four bees (Jordan and Brosemer, 1974; Crain et al., 1976; Rasch, 1985; Petitpierre, 1996; Gadau et al., 2001; Wilfert et al., 2006; The Honeybee Genome Sequencing Consortium, 2006), six wasps (Rasch et al., 1975, 1977; Rasch, 1985; Johnston et al., 2004; Barcenas et al., 2008) and forty two ants (Li and Heinz, 2000; Johnston et al., 2004; Tsutsui et al., 2008).

Corresponding author: M.G Tavares, mtavares@ufv.br

* Manuscript editor: Walter Sheppard
The knowledge of the genome size provides data for comparative studies in a variety of taxonomic levels and groups, for phylogenetic associations and for the design of sequencing projects. Due to this relevance, it is surprising the current lack of data related to the stingless bees' genome size, a group of high eusocial bees, particularly due to their abundance, diversity and important role in the pollination in native forest in Brazil.

Thus, considering that the genome size determination of a species may facilitate the design of further molecular studies, the aims of this research were to: (1) standardize a protocol to obtain adequate nuclei suspension for flow cytometry (FCM) analyses in bees and (2) measure the 2C DNA content of Scaptotrigona xantotricha, Melipona rufiventris and $M$. mondury, in order to provide a starting point for comparative analysis on the patterns of genome size variation in these stingless bees and its relationship to the evolution of sociality in this and in other insect groups. 
Specifically, we choose $S$. xanthotricha, because their colonies produce haploid males all year long, fact that makes this species ideal for use as FCM internal standard. Otherwise, $M$. rufiventris and $M$. mondury were chosen because, due to morphological similarities, until recently they were considered a single species in Minas Gerais state (Melo, 2003) besides being objects of study in our laboratory.

\section{MATERIALS AND METHODS}

\subsection{Biological material}

Samples of Scaptotrigona xanthotricha female and male of post-defecating larvae (prepupal phase) and Melipona rufiventris and $M$. mondury female post-defecating larvae were collected from colonies from Viçosa/MG, Guimarânia/MG and Itamarandiba/MG regions, respectively. The FCM analyses were carried out at the Laboratory of $\mathrm{Cy}$ togenetics and Cytometry, Department of General Biology, Universidade Federal de Viçosa (UFV).

\subsection{Experimental design}

In order to determine a suitable internal standard for FCM measurements in bees and to avoid linearity problems, initially the C DNA content mean value of haploid male $S$. xantotricha was assessed using the adult female Drosophila melanogaster strain Iso-1 (internal standard - C $=0.18 \mathrm{pg}-$ Bennett et al., 2003) obtained from University of California at Berkeley (CA, USA). The nuclear DNA content of the other female bees was measured using the internal standard as shown in Table I.

\subsection{Flow cytometry analysis}

Brain ganglion of the standard and sample were excised in a cooled physiologic solution (Arboreto ${ }^{\circledR}$ ). Using a stereoscopic microscope, intact brain ganglions were carefully excised, transposed to a new drop of same solution and cleaned in order to avoid the contamination by other head tissues. The materials were simultaneously crushed 10 times with a pestle in a tissue grinder (Kontes Glass Company ${ }^{\circledR}$ ) with $100 \mu \mathrm{L}$ OTTO-I lysis buffer (Otto, 1990) containing $0.1 \mathrm{M}$ citric acid
Table I. Internal standards used in the FCM measurements of $S$. xantotricha, $M$. rufiventris and $M$. mondury nuclei samples. The experimental design was applied in the order to prevent FCM linearity problems.

\begin{tabular}{cc}
\hline Sample species & Internal standard species \\
\hline Male $S$. xantotricha & Female D. melanogaster \\
Female $S . x a n t o t r i c h a$ & Male $S . x a n t o t r i c h a$ \\
Female $M$. rufiventris & Female S.xantotricha \\
Female M. mondury & Female S.xantotricha \\
\hline
\end{tabular}

(Merck $\mathrm{KGaA}^{\circledR}$ ), 0.5\% Tween 20 (Merck $\mathrm{KGaA}^{\circledR}$ ) and $50 \mu \mathrm{g} \mathrm{mL}^{-1}$ RNAse (Sigma-Aldrich ${ }^{\circledR}$ ), at to $\mathrm{pH}=2.3$ to minimize enzymatic catalysis. The suspension was adjusted to $1.0 \mathrm{~mL}$ with the same buffer, filtered through $30 \mu \mathrm{m}$ nylon mesh (Partec $\mathrm{Gmbh}^{\circledR}$ ) and centrifuged at $100 \mathrm{~g}$ in Eppendorf tubes for $5 \mathrm{~min}$.

The pellet was then incubated for $10 \mathrm{~min}$ in $100 \mu$ L OTTO-I lysis buffer and stained with $1.5 \mathrm{~mL}$ OTTO-I:OTTO-II (1:2) solution (30 min) (Loureiro et al., 2006a, b) supplemented with $75 \mu \mathrm{M}$ propidium iodide (PI Sigma ${ }^{\circledR}$ - excitation/emission wavelengths: 480-575/550-740 nm, Shapiro, 2003) and $50 \mu \mathrm{g} \mathrm{mL}^{-1}$ RNAse (Sigma-Aldrich ${ }^{\circledR}$ ), $\mathrm{pH}=7.8$. The nuclear suspension was filtered through $20 \mu \mathrm{m}$ diameter mesh nylon filter $\left(\right.$ Partec $\mathrm{Gmbh}^{\circledR}$ ) and maintained in the dark for 5-40 min.

The suspension was analyzed with a Partec PAS $^{\circledR}$ flow cytometer $\left(\right.$ Partec $^{\circledR}$ Gmbh, Munster, Germany) equipped with a Laser source (488 nm). PI fluorescence emitted from nuclei was collected through a RG $610 \mathrm{~nm}$ band-pass filter and converted to 1024 channels. The equipment was calibrated for linearity and aligned with microbeads and standard solutions according to the manufacturer's recommendations. FlowMax ${ }^{\circledR}$ software $\left(\right.$ Partec $\left.^{\circledR}\right)$ was used for data analyses. The standard nuclei peak was set to channel 100 and more than $10000 \mathrm{nu}-$ clei were analyzed. Three independent replications were done and histograms with coefficient of variation (CV) above $5 \%$ were rejected.

The mean genome size of each female bee sample was measured according to formula adapted from Doležel and Bartos (2005):

Sample 2C DNA content $(\mathrm{pg})=$

(Mean $\mathrm{G}_{0} / \mathrm{G}_{1}$ peak of the sample

$\times$ Standard 2C DNAcontent)

$\times\left(\text { Mean } \mathrm{G}_{0} / \mathrm{G}_{1} \text { peak of the standard }\right)^{-1}$. 
For male bee values, the sample 2C DNA content in the formula above was replaced to 1C DNA.

The mean genome sizes will be presented here as $\mathrm{C}$-values in picograms ( $\mathrm{pg}$ ) and megabases pairs (1 pg = 978 Mbp) (Doležel et al., 2003).

\section{RESULTS}

In this study, the genome size of $S$. xantotricha, M. mondury and $M$. rufiventris was adequately measured by FCM. The analyses of the nuclei suspensions stained with PI generated histograms with peaks corresponding to the average relative DNA content of the $\mathrm{G}_{0} / \mathrm{G}_{1}$ nuclei of $S$. xantotricha (male and female), $M$. rufiventris (female), M. mondury (female) and the comparative internal standard (Fig. 1). The histograms showed good resolution levels (Fig. 1a-e) and CVs ranging from 2.87 to $4.14 \%$.

The mean genome size values of male and female $S$. xantotricha was $410.8 \mathrm{Mbp}(\mathrm{C}=$ $0.42 \mathrm{pg})$ and $430.3 \mathrm{Mbp}(\mathrm{C}=0.44 \mathrm{pg})$, respectively (Fig. 1a-b, Tab. II). The mean genome size of $M$. rufiventris and $M$. mondury females was 909.5 $\mathrm{Mbp}(\mathrm{C}=0.93 \mathrm{pg})$ and $929.1 \mathrm{Mbp}$ (C $=0.95 \mathrm{pg}$ ), respectively (Fig. 1c-d, Tab. II). The similarity of these two genome sizes can be confirmed in the histogram of $M$. rufiventris and $M$. mondury nuclei suspension, where the $\mathrm{G}_{0} / \mathrm{G}_{1}$ peaks of both species were not distinguished (Fig. 1e).

\section{DISCUSSION}

The nuclei preparation employed in the present study resulted in suspensions with few artifacts such as fluorescent nonnuclear debris and nuclear aggregates. Crushing in a tissue grinder was also applied by Bennett et al. (2003) and Johnston et al. (2004), but these authors used Galbraith buffer (Galbraith et al., 1983) to generate the nuclei suspensions. In this study, the OTTO buffers (Otto, 1990) were applied for the same purpose. We opted for this buffer because, in our laboratory routine, histograms with high resolution and low CVs have been obtained, as confirmed by the results of this study. Also, Doležel and Bartoš (2005) and Loureiro et al. (2006a, b) recommended the OTTO buffers considering that the citric acid (OTTO-I) prevents differences in staining intensity of the nuclei. In addition, in agreement with Loureiro et al. (2006a, b), these buffers provided better results in species with low DNA content, such as bees.

Aron et al. (2003) applied the chopping procedure and detergent-trypsin buffer solution (Vindelov et al., 1983) for nuclei preparation from Linepithema humile adults and larvae. These authors obtained FCM histograms with $\mathrm{CVs}$ ranging from $4.2 \%$ to $7.3 \%$. In the present study, the largest CV was $4.14 \%$, value that is considered acceptable for FCM measurements (Galbraith et al., 2002), and indicates that the methods and buffers supplied adequate FCM nuclei suspensions.

Additionally, the methodology developed here suitably discriminated the $\mathrm{G}_{0} / \mathrm{G}_{1}$ nuclei of the haploid males and diploid females of S. xantotricha, which consequently strengthens the use of this species as internal standard for FCM analysis in bees, rather than distantly related organisms.

The small difference in the DNA content between males and females of $S$. xantotricha is unlikely to be measurement errors. Our measurements were repeated several times for both sexes simultaneously and demonstrated the same values differences. Additionally, the flow cytometry linearity was checked with standard microbeads and chicken red blood cell suspensions. The exact reasons of this difference, however, remain obscure and only additional studies could clarify this question.

FCM measurements also showed that the genome sizes of $M$. rufiventris and $M$. mondury differed by only $19.6 \mathrm{Mbp}$ but were $\sim 2.1$-fold larger than that of S. xantotricha (Fig. 1c-d, Tab. II). The other few Apidae studied until now also show a smaller genome size than that of $M$. rufiventris and $M$. mondury. For example, Apis cerana, A. mellifera and Bombus terrestris possesses an estimated C-value of $185.8 \mathrm{Mbp}(0.19 \mathrm{pg}$ ) (Jordan and Brosemer, 1974), $262 \mathrm{Mbp}$ (0.268 pg) (The Honeybee Genome Sequencing Consortium, 2006) and $625 \mathrm{Mbp}$ (0.639 pg) (Wilfert et al., 2006). The genome size of these two Melipona species is also larger than the mean 


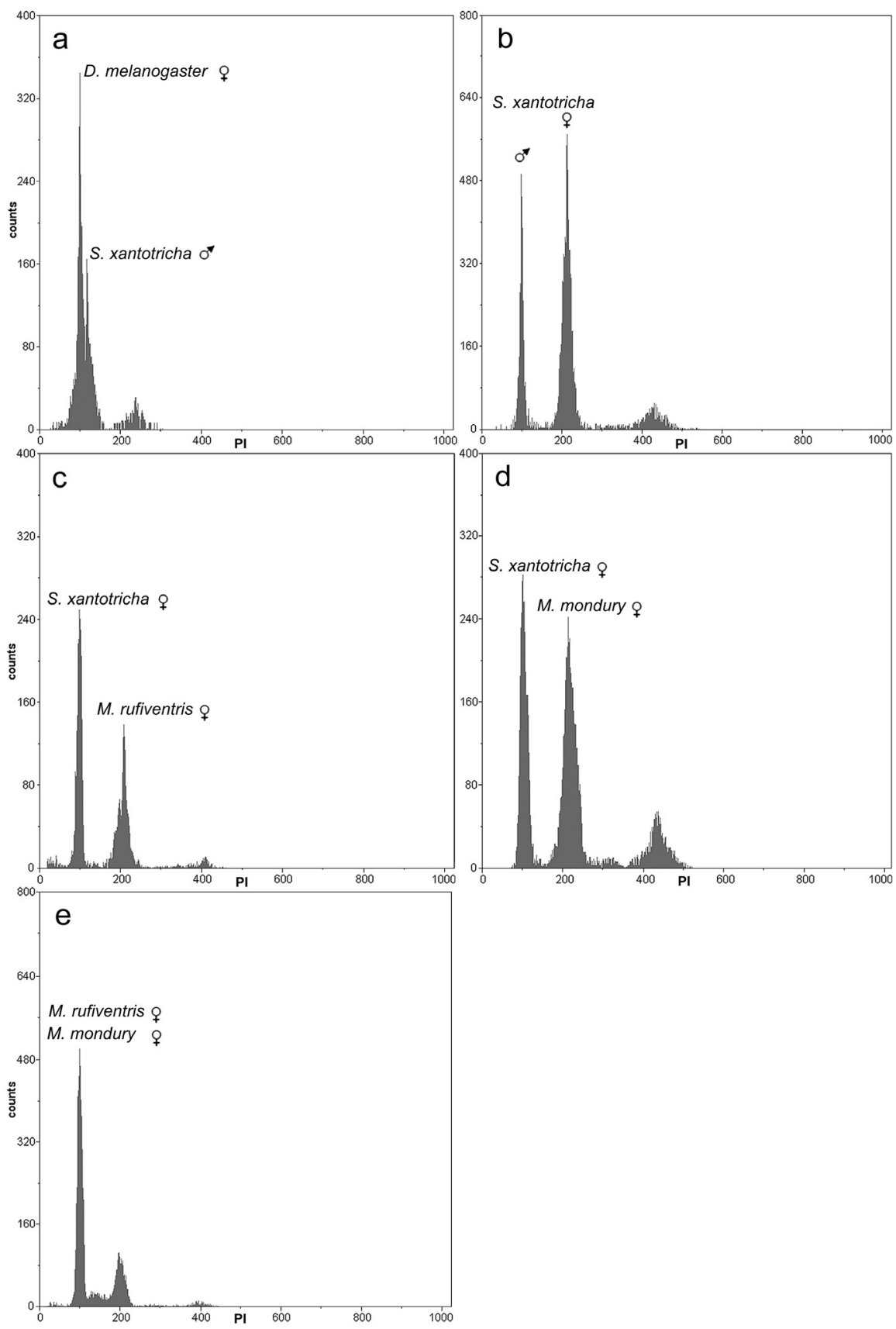

Figure 1. Genome size DNA-histograms of S. xantotricha, M. rufiventris and M. mondury through analysis of nuclear suspensions of cerebral ganglion tissue, stained with PI. (a) Female D. melanogaster (internal standard $2 \mathrm{C}=0.36 \mathrm{pg}$, channel 100$)$ and male $S$. xantotricha $(1 \mathrm{C}=0.42 \mathrm{pg}$, channel 117). (b) Male S. xantotricha $(1 \mathrm{C}=0.42 \mathrm{pg}$, channel 100) and female $S$. xantotricha $(2 \mathrm{C}=0.88 \mathrm{pg}$, channel 210$)$. (c) Female $S$. xantotricha $(2 \mathrm{C}=0.88 \mathrm{pg}$, channel 100$)$ and female $M$. rufiventris $(2 \mathrm{C}=1.85 \mathrm{pg}$, channel 210$)$. (d) Female $S$. xantotricha $(2 \mathrm{C}=0.88 \mathrm{pg}$, channel 100$)$ and female $M$. mondury $(2 \mathrm{C}=1.89 \mathrm{pg}$, channel 215). (e) Female M. mondury (channel 100) and female M. rufiventris (channel 100). 
Table II. Genome estimation size of cerebral ganglion of S. xantotricha, M. rufiventris and M. mondury.

\begin{tabular}{ccc}
\hline Species & $\begin{array}{c}\text { Mean genome size }(1 \mathrm{C}) \\
(\mathrm{pg} \text { and Mbp) }\end{array}$ & $\begin{array}{c}\text { Mean genome size/nucleus }\left(\mathrm{G}_{1}\right) \\
(\mathrm{Mbp})\end{array}$ \\
\hline Male S. xantotricha & $0.42-410.8$ & 410.8 \\
Female S. xantotricha & $0.44-430.3$ & 860.6 \\
Female M. rufiventris & $0.93-909.5$ & 1819.0 \\
Female M. mondury & $0.95-929.1$ & 1858.2 \\
\hline
\end{tabular}

size estimated for the hymenopteran species (352 Mbp; C $=0.36$ pg - Gregory, 2008) analyzed to date.

Cytogenetic studies have allowed the division of several Melipona species with the same number of chromosomes $(2 \mathrm{n}=18)$ in two groups based on their heterochromatin content. The first group comprises species with low heterochromatin content (M. bicolor, M. quadrisfasciata, M. asilvai, $M$. marginata and $M$. subnitida), while species in the second one (M. capixaba, M. compressipes, M. crinita, M. seminigra, M. captiosa, M. scutellaris, M. rufiventris and M. mondury) contain a high heterochromatin content (Rocha and Pompolo, 1998; Rocha et al., 2002; Lopes et al., 2008).

In this context, one mechanism that could give raise to the extra-DNA in $M$. rufiventris and $M$. mondury is the higher heterochromatin amount in the chromosomes of these species (Lopes et al., 2008) compared to S. xantotricha (Rocha et al., 2003). Boulesteix et al. (2006) have also mentioned that the large heterochromatin amount present in the chromosomes of Drosophila orena may be the main factor responsible for the greater increase in the genome size of this species in comparison to the others species of the Drosophila melanogaster subgroup.

Increases in genome size, however, have also been associated with transposable elements (TEs) (SanMiguel and Bennetzen, 1998; Vieira et al., 2002), repetitive sequences (Uozu et al., 1997; Ullmann et al., 2005), intron size (Moriyama et al., 1998) and microsatellite presence (Warner and Noor, 2000).

The variation among the genome sizes of the species analyzed herein may, therefore, reflect differences in their genomic structure. Nevertheless, no extrapolations should be made about the evolutive significance of the differences observed since we had estimated the genome size for only three stingless bees. Anyway, only a closer examination of genetic characteristics such as number of TEs, introns size and microsatellite size and number may elucidate the specific mechanisms by which their genomes expanded or contract. These studies should help us to understand the link between chromatin structure, genome size and evolution of the stingless bees.

Anyway, despite the high genomes sizes of $M$. rufiventris and $M$. mondury in comparison to the genome size of $S$. xanthotricha and other Hymenoptera species, our results still match the pattern verified for species that undergo complete metamorphosis, presenting genomes that are smaller than $\mathrm{C}=2 \mathrm{pg}$ (Gregory, 2002, 2005). Thus, our data represent a significant step towards a better understanding of the stingless bee genome.

\section{ACKNOWLEDGEMENTS}

The authors thank FAPEMIG for financial support given to the projects EDT 245/05 and CBB APQ-0858-3.12/07, CNPq and to CAPES for the grant ceded to D.M. Lopes.

Estimation de la taille du génome de trois espèces d'abeilles sans aiguillon (Hymenoptera, Meliponinae) par cytométrie de flux.

Apoidea / abeille sans aiguillon / taille du génome / cytométrie de flux

Zusammenfassung - Schäztung der Genomgröße von drei Stachellosen Bienenarten (Hymenoptera, Meliponinae) mittels Durchflusszytometrie. Kenntnisse über Genomgrössen sind von Bedeutung für den Entwurf von Sequenzierungesprojekten und für vergleichende Studien 
unterschiedlicher taxonomischer Gruppen. Nichtsdestoweniger ist die Genomgröße verschiedener Insektengruppen, einschliesslich der Stachellosen Biene nahe unbekannt, trotz ihrer ökologischen Bedeutung. Ziele dieser Untersuchung waren: (1) die Standardisierung eines Protokolls zur Gewinnung von Zellkernen für Durchflusszytometrieanalysen (FCM) bei Bienen, und (2) die Bestimmung des DNA-Gehalts für Scaptotrigona xantotricha, Melipona rufiventris und M. mondury, als Startpunkt für vergleichende Analysen der Variation der Genomgrössen Stachelloser Bienen. Das entwickelte Protokoll (Tab. I) erlaubte es, adequate Kernsuspensionen mit niedrigem Fluoreszenzhintergrund bedingt durch Kernfragmente und andere Organelle zu gewinnen, und es lieferte Histogramme mit Variationskoeffizienten zwischen 2,87 und 4,14 \% (Abb. 1). Der mittlere DNA-Gehalt für Männchen von $S$. xantotricha lag bei $0,42 \mathrm{pg}$ (410,8 Mbp), der von Weibchen betrug 0,44 pg (430,3 Mbp). Für M. rufiventris betrug die Größe des haploiden Genoms 0,93 pg (909,5 Mbp) und für M. mondury lag der Wert bei 0,95 pg (929,1 Mbp) (Tab. II). Diese Unterschiede im DNA-Gehalt könnten ihre Ursache in unterschiedlichen Heterochromatingehalten der Chromosomen von Scaptotrigona und MeliponaArten haben. Die Ergebnisse stellen einenAusgangspunkt für vergleichende Untersuchungen zur Genomgröße und der entsprechenden Variationen bei Stachellosen Bienen dar.

\section{Durchflusszytometrie / Genomgröße / Hymeno- ptera / Stachellose Bienen}

\section{REFERENCES}

Aron S., de Menten L., Van Bockstaele D.R. (2003) Brood sex ratio determination by flow cytometry in ants, Mol. Ecol. Notes 3, 471-475.

Barcenas N.M., Thompson N.J., Gomez-Tovar V., Morales-Ramos J.A., Johnston J.S. (2008) Sex determination and genome size in Catolaccus grandis (Burks, 1954) (Hymenoptera: Pteromalidae), J. Hymenoptera Res. 17, 201-209.

Bennett M.D., Leitch I.J., Price H.J., Johnston J.S. (2003) Comparisons with Caenorhabditis $(\sim 100 \mathrm{Mb})$ and Drosophila $(\sim 175 \mathrm{Mb})$ using flow cytometry show genome size in Arabidopsis to be $\sim 157 \mathrm{Mb}$ and thus $\sim 25 \%$ larger than the Arabidopsis genome initiative estimate of $\sim 125 \mathrm{Mb}$, Ann. Bot. 91, 547-557.

Boulesteix M., Weiss M., Biémont C. (2006) Differences in genome size between closedy related species: the Drosophila melanogaster species subgroup, Mol. Biol. Evol. 23, 162-167.

Crain W.R., Davidson E.H., Britten R.J. (1976) Contrasting patterns of DNA sequence arrange- ment in Apis mellifera (honeybee) and Musca domestica (housefly), Chromosoma 59, 1-12.

Doležel J., Bartos J. (2005) Plant DNA flow cytometry and estimation of nuclear genome size, Ann. Bot. 95, 99-110.

Doležel J., Bartos J., Voglmayr H., Greilhuber J. (2003) Nuclear DNA content and genome size of trouts and human, Cytometry 51A, 127-128.

Gadau J., Gerloff C.U., Krügers N., Chan H., Schmid-Hempel P., Wille A., Page R.E.J. (2001) A linkage analysis of sex determination in Bombus terrestris (L.) (Hymenoptera: Apidae), Heredity 87, 234-242.

Galbraith D.W., Harkins K.R., Maddox J.M., Ayres J.M., Sharma D.P., Firoozabady E. (1983) Rapid flow cytometric analysis of the cell cycle in intact plant tissue, Science 220, 1049-1051.

Galbraith D.W., Lambert G.M., Macas J., Dolezel J. (2002) Analysis of nuclear DNA content and ploidy in higher plants, in: Robinson J.P., Darzynkiewicz Z., Dean P.N., Dressler L.G., Rabinovitch P.S., Stewart C.V., Tanke H.J., Wheeless L.L. (Eds.), Current protocols in cytometry, John Wiley \& Sons, New York, pp. 761-862.

Gregory T.R. (2002) Genome size and developmental complexity, Genetica 115, 131-146.

Gregory T.R. (2005) The C-value enigma in plants and animals: a review of parallels and an appeal for partnership, Ann. Bot. 95, 133-146.

Gregory T.R. (2008) Animal Genome Size Database, [online] http://www.genomesize.com (accessed on 17 February 2009).

Johnston J.S., Ross L.D., Beani L., Hughes D.P., Kathirithamby J. (2004) Tiny genomes and endoreduplication in Strepsiptera, Insect Mol. Biol. $13,581-585$.

Jordan J.R., Brosemer R.W. (1974) Characterization of DNA from three different bee species, J. Insect Physiol. 20, 2513-2520.

La Salle J., Gauld I.D. (1993) Hymenoptera and Biodiversity, Leaper and Gard Ltda, Bristol.

Li J., Heinz K.M. (2000) Genome complexity and organization in the red imported fire ant Solenopsis invicta Buren, Genet. Res. Camb. 75, 129-135.

Lopes D.M., Pompolo S.G., Tavares M.G., Campos L.A.O. (2008) Cytogenetic characterization of Melipona rufiventris Lepeletier 1836 and Melipona mondury Smith 1863 (Hymenoptera: Apidae) by $\mathrm{C}$ banding and fluorochromes, Genet. Mol. Biol. 31, 49-52.

Loureiro J., Rodriguez E., Doležel J., Santos C. (2006a) Comparison of four nuclear isolation 
buffers for plant DNA flow cytometry, Ann. Bot. 98, 679-689.

Loureiro J., Rodriguez E., Doležel J., Santos C. (2006b) Flow cytometric and microscopic analysis of the effect of tannic acid on plant nuclei and estimation of DNA content, Ann. Bot. 98, 515-527.

Melo G.A.R. (2003) Notas sobre meliponíneos neotropicais (Hymenoptera, Apidae), com a descrição de três novas espécies, in: Melo G.A.R., Santos I.A. (Eds.), Apoidea Neotropica. Homenagem aos 90 anos de Jesus Santiago Moure, UNESC, Santa Catarina, Brasil, pp. 85-92.

Moriyama E.N., Petrov D.A., Hartl D.L. (1998) Genome size and intron size in Drosophila, Mol. Biol. Evol. 15, 770-773.

Otto F.J. (1990) DAPI staining of fixed cells for high-resolution flow cytometry of nuclear DNA, in: Darzynkiewiez Z., Crissman H.A., Robinson J.P. (Eds.), Methods in Cell Biology, Vol. 33, Academic Press, San Diego, pp. 105-110.

Petitpierre E. (1996) Molecular cytogenetics and taxonomy of insects, with particular reference to the coleopteran, Int. J. Insect Morphol. Embryol. 25, 115-134.

Rasch E.M. (1985) DNA "standards" and the range of accurate DNA estimates by Feulgen absorption microspectrophotometry, in: Cowden R.R., Harrison S.H., (Eds.), Advances in Microscopy, Progress in Clinical and Biological Research, Vol. 196, New York, pp. 137-166.

Rasch E.M., Cassidy J.D., King R.C. (1975) Somatic cell DNA content in haploid, diploid, and triploid adults of Mormoniella vitripennis, J. Cell Biol. 67, 353A.

Rasch E.L., Cassidy J.D., King R. (1977) Evidence for dosage compensation in parthenogenetic Hymenoptera, Chromosoma 59, 323-340.

Rocha M.P., Pompolo S.G. (1998) Karyotypes and heterochromatin variation (C-bands) in Melipona species (Hymenoptera, Apidae, Meliponinae), Gen. Mol. Biol. 21, 41-45.

Rocha M.P., Pompolo S.G., Campos L.A.O. (2003) Citogenética da tribo Meliponini (Hymenoptera, Apidae), in: Melo G.A.R., Santos I.A. (Eds.),
Apoidea Neotropica. Homenagem aos 90 anos de Jesus Santiago Moure, UNESC, Santa Catarina, Brasil, pp. 311-320.

Rocha M.P., Pompolo S.G., Dergam J.A., Fernandes A., Campos L.A.O. (2002) DNA characterization and karyotypic evolution in the bee genus Melipona (Hymenoptera Meliponini), Hereditas 136, 19-27.

SanMiguel P., Bennetzen J.L. (1998) Evidence that a recent increase in maize genome was caused by the massive amplification of intergene retrotransposons, Ann. Bot. 81, 37-44.

Shapiro H.M. (2003) Practical flow cytometry, 4th edn. John Wiley \& Sons, New Jersey.

The Honeybee Genome Sequencing Consortium (2006): Insights into social insects from the genome of the honeybee Apis mellifera, Nature 443, 931-949.

Tsutsui N.D., Suarez A.V., Spagna J.C., Johnston J.S. (2008) The evolution of genome size in ants, BMC Evol. Biol. 8, 1-9.

Ullmann A.J., Lima C.M.R., Guerrerot F.D., Piesman J., Black W.C. (2005) Genome size and organization in the blacklegged tick, Ixodes scapularis, and the Southern cattle tick, Boophilus microplus, Insect Mol. Biol. 14, 217-222.

Uozu S., Ikehashi H., Ohmido N., Ohtsubo H., Ohtsubo E., Fukui K. (1997) Repetitive sequences: cause for variation in genome size and chromosome morphology in the genus Oryza, Plant Mol. Biol. 35, 791-799.

Vieira C., Nardon C., Arpin C., Lepetit D., Biemont C. (2002) Evolution of genome size in Drosophila. Is the invader's genome being invaded by transposable elements? Mol. Biol. Evol. 19, 1154-1161.

Vindelov L.L., Christensen I.J., Keiding N., Nissen N.I. (1983) A detergent-trypsin method for the preparation of nuclei for flow cytometric DNA analysis, Cytometry 3, 323-327.

Warner R.D., Noor M.A. (2000) High frequency of microsatellites in Drosophila pseudoobscura, Genes Genet. Syst. 75, 115-118.

Wilfert L., Gadau J., Schmid-Hempel P. (2006) A core linkage map of the bumblebee Bombus terrestris, Genome 49, 1215-1226. 